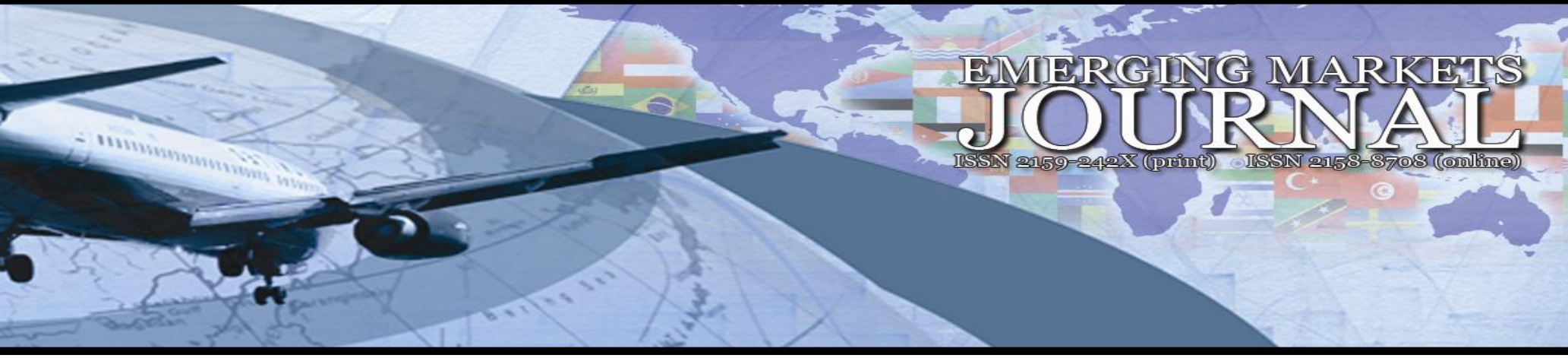

\title{
A New Path for Management Education in an Emerging Country
}

\section{Ayşe Çoban Kayacı}

Istanbul Medeniyet University, Department of Management | ayse.coban@medeniyet.edu.tr

Volume 6 No 2 (2016) ｜ ISSN 2158-8708 (online) | DOI 10.5195/emaj.2016.110 | http://emaj.pitt.edu |

\begin{abstract}
Management education has a long history in Turkey, but it still has so many structural problems. Both scholars and practitioners complain about the inconsistencies with theoretical and practical sides of university education in the management field. Lack of critical thinking and ethical values have become first hand problems of management education both globally and nationally. This study focuses on the evolution of management education and its historical problems in the light of global perspectives. Suggestions to solve intrinsic matters in university education for a better human resource quality and business life for Turkey have been made.
\end{abstract}

Keywords: management education, Turkey, critical thinking, curriculum development $(\mathrm{cc}) \mathrm{Br}$

New articles in this journal are licensed under a Creative Commons Attribution 3.0 United States License.

\section{UILIS D-Soth}

This journal is published by the University Library System of the University of Pittsburgh as part of its $\underline{\mathrm{D} \text {-Scribe Digital Publishing Program, and is cosponsored by the University of Pittsburgh Press. }}$ 


\section{A NEW PATH FOR MANAGEMENT EDUCATION IN AN
EMERGING COUNTRY}

\author{
Ayşe Çoban Kayacı
}

\section{Introduction}

It becomes a necessity that management education needs to be restored for the post-industrial requirements of business environment. An overall assessment of management education in higher education may contribute new paths for the applicants of business life. Although, it seems that the winner of the terrain of management education is North American school, there have been local applications and resistances for higher education in management field.

The globalization process helped North American style to win this battle. In the post-industrial era, studying business has become so popular for students from different disciplines in most of the countries (Bruner and Iannarelli, 2011). Moreover, the evolution of management education has been discussed for Europe and Mediterranean Europe by most of the academicians in management field since 1960s. ${ }^{1}$ Expanding markets, new business fields, social changes, increased mobilization and e-business activities need more talented and professional labor force. Most of the business schools try to educate students according to needs of business environment, but the education style still remains as absolute teaching for the students. Traditional classroom teaching has started to be ineffective for inexperienced students to develop organizational understandings (Shaw and Fisher, 1999). This study will discuss the history of management education in Turkey, different applications to restore higher education in different countries and a critical perspective of managerial thought in today's business life.

\section{History of Management Education in Turkey}

The lack of critical thinking is an obstacle for management education in Turkey. Ozcan (2012), mentioned this problem by showing the immaturity of critical management studies which has been made so far. To understand the management education and its problems, it is an obligation to assess the history of management education of Turkey.
The seeds of management education in Turkey have started to grow up in 1882 by constituting "higher" school of commerce in Istanbul. The education style of this school was affected from French "grandes écoles" because of the cyclical environment of Ottoman Empire. After the foundation of the Republic of Turkey, this school has become a faculty of Istanbul University and the effect of Continental Europe had been noticed in the style of education. In the second evolution of management education, the "higher" commerce schools had transformed into Academies of Economics and Commerce and the French school effect left its place to German effect in the management education area. In the third evolution, with the constitution of Middle East Technical University and Robert College, the management education was started to be dominated by the American style. The government's economic applications and post-war conditions of the world also affected the country's education system. The new universities had a new position in the education system of country by applying American management education style and teaching the courses in English. Moreover, the business environments in the country demand more professional labor force and managers to employ in developing industrial firms (Kipping, Usdiken, and Puig, 2004; Sargut, 2009). In accord with these improvements, the education style has evolved to train individuals for managerial positions of the private sector organizations in management field (Üsdiken, 2009). It has been accepted by most of the academicians in management field that Turkey's late industrialization and financialization has served the domination of American style in managerial thought and education (Kipping, Usdiken, and Puig, 2004; Sargut 2009). Actually, the influence of American style in managerial thought and education was perceived in Europe as well. However, the European style was seen as more abstract cause of "business economics" and tended to be less disposed to train professional management (Kast, 1965).

\section{Praxis for a New Style and Critical Aspects}

In the post-industrial era, the economic crisis and financial scandals in business environment have made the managerial thinkers to re-think about the importance of values in management education. The transition of the values and ethics to management students has also been a problem for academicians. A special framework has been mentioned by Moosmayer and Bode (2010) to support a worldwide comprehension of different cultures and traditions about the effect of academicians on the values. This is to make clear precise hypotheses about academics' influence on students and business environments and to develop management education (Moosmayer and Bode, 2010). This framework can contribute a different perspective for Turkish academia in management field. In the shadow of market 
oriented view, the business life has sheltered all the risks of corrupt practices and financial scandals in Turkey as well. Focusing on managerial values and ethics would brighten the students for the practical side of management field and their future work lives. Students can achieve to assimilate the importance of values and ethics with the help of independent knowledge. Furthermore, it is globally very important to have an MBA degree and MBA holders have their own "habitus" which is highly oriented with "market capitalism". There is a risk for MBA programs to reinforce unethical values and practices of "habitus". For instance, the accreditation institutions can be a double edged sword for business schools and MBA programs to replace unethical standards and practices or to maintain preconceived values (Vaara and Faÿ, 2011). The research of O'Donovan (2010) in UK has shown that most of the undergraduate students in management field tend to gather absolute and transitional knowledge. The students at the undergraduate level generally want the definite knowledge about the lectures from their teachers or they try to categorize the knowledge in their lectures (O'Donovan, 2010). This is an alert for managerial thought, since it ignores to criticize the knowledge of management discipline. The students may have so many problems in their work life when they would try to solve the conflicts with absolute knowledge they got from their undergraduate education.

Unfortunately, critical thinking and learning is not so common in Turkish society. The cultural context and social factors may have an important effect on epistemological beliefs (O'Donovan, 2010). Because of this effect, the examples or cases in management education classes would not be so applicable for the students. Even if the students get the absolute information from their undergraduate classes, they would fall in trouble to connect real life situations. Most of the cases and applications in management classes are from American books or articles and most of the times the solutions can't respond local needs of business life.

Another study has been offered by Rousseau (2007) to assemble the practical and theoretical side of management education. An online access portal that helps the researchers, educators and practitioners to meet and discuss the practical questions, problems and research results is called as the Evidence Based Management Collaboration (EBM) (Rousseau, 2007). Rousseau (2007) thinks that EBM can be a pivot to transfer the abstract knowledge of organization science into the practices of business life. This praxis would be beneficial for Turkish management education to constitute a local case database to respond our local problems since the imported cases in management classes try to impose an American managerial thought. The changes in management education would need an institutional policy to sustain the new style of education.
However, universities with powerful and professionalized faculty members may resist to develop an institutional policy and follow it (Kraatz, Ventresca, and Deng, 2010).

It has become so common to constitute partnerships among business schools. Most of the business schools in the world (about $65 \%$ ) have developed partnerships with U.S. business schools. According to reports, European business schools have the highest level of this ratio by having one or more partners for each business school from all over the world (Bruner and Iannarelli, 2011). Even though adopting the management education into the local needs of business environment is important, Turkish business schools should create new partnerships especially with European business schools to eliminate American style management education and to bring a more critical perspective to the field. There is evidence about the lack of studies for critical management thinking in the management field of Turkey. Ozcan (2012) has proved that by his study about investigating the proceedings which was presented in National Management Organization Conference since 1993. The results of the study have shown that there have been a high level of studies about bullying and mobbing, gender based power relations, discrimination, sexual harassment, managerialism, etc. which can't be ignored since the topics are related to critical thinking. However, these topics generally have focused on "behavioral" part of management field. The study shows that Turkish management education has grown an adequate critical approach in behavioral field of organizational study and these attempts probably would have reflections in classroom teaching (Ozcan, 2012). Students should be imposed to criticize about the facts of business life by expanding the topics about power relationships, discrimination, sexual harassment and performance based evolutions in management departments. Even though there has been a spreading for cognitive approaches in the latest years, the academicians should focus on the critical aspects of these approaches.

Besides the need for critical thinking in management studies and education in Turkey, management scholars should focus much more on social responsibility issues in organizations. It has been criticized that managers don't use social sciences for social responsibility in management and they prefer to struggle with age-old problems of costs and employee loyalty by the help of social sciences. At this point, social scientists have been seen as the collaborators of managerial elites to dominate the employees (Baritz, 2005). Furthermore, management education is seen as so ideological because of its assistance to foster the internal solidarity of management and to support managerial authority over subordinates (Anthony, 2005). Since the cognitive approaches have imposed the individuals to 
behave in performance focused base, critical understandings can eliminate the pressures for the individuals. In addition to social responsibility issues, sustainability in management education could be significant for both practical and theoretical aspects. Sustainability can be achieved by curricular and cocurricular learning as well as effective decision makers in business schools (Rusinko, 2010). Unfortunately, Turkish business schools generally suffer from chopping and changing curriculums according to decision makers' education profiles rather than the needs of students and business life. However, sustainability has become a popular issue for business firms, which management scholars deal with. There is an urgent need for arranging curriculums for sustainability oriented view in lectures and contribute to it by supporting both students and academic staff practice sustainability activities. Likewise, graduating managers of future should have basic skills and knowledge about research and development oriented firms. At this point, it has been highly recommended by scholars to develop curriculums with the help of science courses. Science courses are seen as good sources for cultivating critical thinking and inductive reasoning of management students. Collaboration with science and art faculties is seen as a must to have rich curriculums in management or business departments and schools (Ledley and Holt, 2014). In the manner of collaboration with other scientific fields, Turkish business schools or management departments still lack a lot. Most of the students cannot show success in math lessons and there have been so few examples which have a philosophy of science lecture at undergraduate level.

Moreover, business schools have shown a great loyalty to the benefits of high status shareholders until this time (Emiliani, 2006). This situation is similar in Turkey. At this point, Emiliani (2006) has suggested that business schools should train their students for considering all stakeholders' benefits in organizations and a "human-economic" approach should be accepted to designate the principles for distributing the benefits. In Turkish management field, the lack of critical management studies has strengthened the domination of supporting top management privileges and a "humaneconomic" approach for management classes is also applicable for a better education style. Another advice of Emiliani (2006) for improving management education is teaching students to focus on not only the results, but also the processes of activities in every department of organizations. A systematic approach would be beneficiary to fully understand all of the operations and problems in the organizations (Emiliani, 2006). System thinking has become popular in management field since 1960s and a holistic view has brought to light so many managerial problems (Scott, 2003). However, when it comes to management education, the classroom teaching methods and academic research become distinct. It should become common to consider the topics of organizational field with the relations among other study areas. It is known that organizational field is a transdisciplinary study area, but in classroom teaching it can be hard to understand the relations of topics in one lecture with other lectures of the area. The lecturers of organizational field should build up the bridges between Organizational Behavior classes and Human Resources Management classes or Strategic Management classes and Organization Theory classes. By this way, management students can overcome business problems in their future life. However, business schools and management scholars cannot be adequate for bridging the theoretical and practical sides of the field since they are reluctant to learning. Most of the business schools are not reflexive and they don't adopt the idea of "education for change" rather than "change in education". In the present view of change idea in business schools, individuals can learn through higher education. On the other hand, in organizational learning literature, change is possible with learning within higher education. Most of the business schools in western countries are highly concerned with ranking issues which are short term problems. It is similar for Turkish business schools. They are interested to gather the attention of successful students in university entrance exams and make them to choose their institutions among other schools. However, having the students with greatest scores is not sustainable to be a prestigious business school in the long run. Some of prestigious business schools in Turkey suffer from awkward organization structures and can fail to meet the expectations of successful students. This awkwardness generally results from academicians' and management's behavior for not being open to criticism. Individual learning cannot be separated from organization learning, especially for education institutions (Solitander et al., 2011).

In addition to considering all shareholders' benefits, human resources development topic is important for management education. Holden and Griggs (2011) have claimed that HRD is usually taught with a managerialist perspective. Their study has supported the idea of evaluating the human resources politics more in human resources management classes to prepare the students for real business problems. The condition of having a more critical curriculum has been partially achieved in their business department. Also, another claim of them is that, having a critical curriculum can provide advanced critical management thinking in their classes (Holden and Griggs, 2011). This approach should be considered with the need for critical studies for management in Turkey and can be applied to improve Human Resources Management courses. Since there has not been enough research outputs about Human Resources Management topics and graduate programs in Turkish universities, organizations may abstain from getting support of management scholars. As a result, most of business organizations may prefer global 
research outputs about Human Resources Management problems and still suffer the inconsistency of solutions with Turkish cultural context (Aycan, 2001). These problems are another indicator for insufficient and reluctant management education as well as organizations in Turkish universities. As mentioned before, business schools and scholars should be more open to criticism and not undermine the needs of practical side. Academicians may try to collaborate with practitioners when conducting research in Human Resources Management and other fields of management education.

Another important point for management education is its relation with research field. Studies have shown that, a positive correlation can be seen between high quality teaching and high quality research (James, 2011). This point should also be considered for the Turkish case. High quality research has generally been made possible by old business schools or private universities. The business schools in Anatolian universities still struggle for qualified academic stuff for high quality research and education. A more homogeneous distribution of academic staff has to be accomplished for the future of business education.

\section{Conclusion}

Most of the examples of this paper have been derived from American or British academic studies. The content of these studies have an aim of improving the management education in business schools. As expected from American style, the advices and applications of education improvement studies are generally firm or stakeholder oriented. On the other hand, studies from British academicians have opened a new direction for management education with a critical and individual oriented perspective. Most of the praxis and suggestions in this paper depend on the critical perspective of British or European style in managerial thought. However, developing and changing economic conditions of Turkey can't be isolated from American type managerial thought. Because of this situation, management lecturers and academicians have to combine these different styles to consider the beneficiaries of all the stakeholders in organizations. New research areas should be filtered with a critical thought not to exploit lower level employees in business life. A more comprehensive study can be made to understand additional needs of management education in Turkey. Curriculums of business schools would be key evidences for a future study.

\section{REFERENCES}

Anthony, PD. 2005. "Management Ideology " In Critical Management Studies: A Reader, edited by Christopher Grey and Hugh Willmott, 21-28. Oxford: Oxford University Press.

Aycan, Zeynep. 2001. "Human resource management in Turkey - Current issues and future challenges." International Journal of Manpower 22 (3):252-260. doi: $10.1108 / 01437720110398347$.

Baritz, Loren. 2005. "The Servants of Power." In Critical Management Studies: A Reader, edited by Christopher Grey and Hugh Willmott, 29-45. Oxford: Oxford University Press.

Bruner, Robert F., and Juliane Iannarelli. 2011. "Globalization of Management Education." Journal of Teaching in International Business 22 (4):232-242. doi: 10.1080/08975930.2011.653908.

Emiliani, ML. 2006. "Improving management education." Quality assurance in Education 14 (4):363-384.

Holden, Rick, and Vivienne Griggs. 2011. "Teaching the politics of HRD: A journey in critical curriculum development." The International Journal of Management Education 9 (2):71-81. doi: 10.3794/ijme.92.307.

James, Simon. 2011. "Does business school research have to be excellent to benefit business school teaching?" The International Journal of Management $\begin{array}{lll}\text { Education } \quad 9 & \text { (2):37-47. doi: }\end{array}$ 10.3794/ijme.92.322.

Kast, Fremont E. 1965. "Management education in Europe." Academy of Management Journal 8 (2):75-89.

Kipping, Matthias, Behlul Usdiken, and Núria Puig. 2004. "Imitation, tension, and hybridization: multiple" Americanizations" of management education in Mediterranean Europe." Journal of Management Inquiry 13 (2):98. 
Kraatz, Matthew S, Marc J Ventresca, and Lina Deng. 2010. "Precarious values and mundane innovations: Enrollment management in American liberal arts colleges." Academy of Management Journal 53 (6):1521-1545.

Ledley, Fred D, and Stephen S Holt. 2014. "Learning objectives and content of science curricula for undergraduate management education." Journal of Management Education 38 (1):86-113.

Moosmayer, Dirk C., and Matthias Bode. 2010. "A conceptual framework for management academics' behavioural intention to influence students' and companies' values." The International Journal of Management Education 9 (1):67-80. doi: 10.3794/ijme.91.259.

O'Donovan, Berry. 2010. "Filling a pail or lighting a fire? The intellectual development of managment undergraduates." The international journal of management education 9 (1):1-10.

Ozcan, Kerim. 2012. "From the Frankfurt School to business schools: critical management studies in Turkey." International Journal of Organizational Analysis 20 (1):107-123. doi: 10.1108/19348831211215696.

Rousseau, Denise M. 2007. "A sticky, leveraging, and scalable strategy for high-quality connections between organizational practice and science." Academy of Management Journal 50 (5):1037-1042.

Rusinko, Cathy A. 2010. "Integrating sustainability in management and business education: A matrix approach." Academy of Management Learning \& Education 9 (3):507-519.

Sargut, A Selami. 2009. "Türkiye'de işletme yönetimi eğitiminin kurumsal çerçevesi: çeşitlilikten eşbiçimliliğe." Eskişehir Osmangazi Üniversitesi İ̈BF Dergisi, Nisan 4 (1):51-63.

Scott, W Richard. 2003. "Organizations as Open Systems." In Organizations: Rational, Natural, and Open Systems. Pearson Education International.
Shaw, James B, and Cynthia D Fisher. 1999. "Practical organizational behavior education (PROBE): Modifications and innovations." Journal of Management Education 23 (1):13-30.

Solitander, Nikodemus, Martin Fougère, André Sobczak, and Heidi Herlin. 2011. "We are the champions: Organizational learning and change for responsible management education." Journal of Management Education:1052562911431554.

Üsdiken, Behlül. 2009. "Bir örgütsel alanin yeniden sekillenisi: Türkiye'de is hayatina yönelik yüksek ögretimde degisim, 1955-1975." METU Studies in Development 35:1.

Vaara, Eero, and Eric Faÿ. 2011. "How can a Bourdieusian perspective aid analysis of MBA education?" Academy of Management Learning \& Education 10 (1):27-39.

\section{Notes}

The idea is derived from the articles of Kipping, Üsdiken and Puig (2004) and East (1965), finance and law. 367-389. 